\title{
KOMPARÁCIA ČINITELOV INTERNETOVEJ EKONOMIKY NA SLOVENSKU A V RÁMCI EURÓPSKEJ ÚNIE
}

\author{
Eva Kianičková
}

\section{Úvod}

Internet od svojho samotného vzniku bol vnímaný predovšetkým ako komunikačný prostriedok. Využitím v súkromnej sfére, resp. pre účely jednotlivca našiel uplatnenie vo vzdelávacích, marketingových či podnikových aktivitách. Internet je významným fenoménom dnešnej doby, čo z makroekonomického hl'adiska má čoraz väčší vplyv aj na samotnú ekonomiku. Klasické odvetvia sa transformovali a prispôsobili podmienkam internetu. Poradenská spoločnost' Boston Consulting Group (BCG) odhaduje, že v nasledujúcich piatich rokoch sa internetová ekonomika členov G20 zvýši zo súčasných 2,5 bilióna na 4,2 bilióna USD. Celosvetový podiel obyvatel'stva s prístupom na internet sa v roku 2010 pohyboval okolo 1,9 miliardy obyvatel'ov. Od svojho vzniku bol internet dominantou USA. Odhaduje sa, že americký podiel na globálnej trhovej ekonomike je dnes $33 \%$, pričom do budúcna by mal mat' klesajúcu tendenciu a klesnút' na $25 \%$, z dôvodu zvyšovania penetrácie širokopásmového prístupu na internet v Európe a Ázií. Článok je zameraný na aspekty, ktoré ovplyvňujú výkonnost' a napomáhajú identifikovat' závislosti a vplyv na samotnú internetovú ekonomiku. Pri analýze vplyvu internetových činitel'ov ovplyvňujúcich internetovú ekonomiku sa vychádzalo z údajov Štatistického úradu SR ako aj z materiálov Európskej únie. Prieskum Statistického úradu SR bol vykonaný na vzorke 4500 respondentov (rok 2010 a 2011), pričom v rámci domácnosti bol vybraný jednotlivec vo veku viac 16 rokov. [6][3]

\section{Komparácia činitel'ov internetovej ekonomiky na Slovensku a v rámci Európskej únie}

Internetové pripojenie zaznamenalo za posledný rok významný pokrok. Stáva sa dostupnejší vo viacerých geografických polohách, a tým aj pre samotných občanov. Avšak celkový počet obyvatel'ov pripojených k internetu v rámci Slovenska je stále za dlhodobým európskym priemerom. Internet zasiahol ako osobný, tak aj podnikatel'ský sektor. Vytvoril podmienky pre vznik nových odvetví, inováciu pôvodných, zmenu off-line na on-line nakupovania, pričom sa začali formovat' aj nové základne on-line spotrebitel'ov a firiem, ktoré sa s pomocou internetu stávajú úspešnejšie práve tým, že využívajú výhody internetového prostredia. Prevažne v rámci EÚ ako aj vo východných krajinách je internetová ekonomická sila pomerne nová. Ale za to má dlhodobo priaznivé vyhliadky na svoj rozvoj. Medzi činitele, ktoré majú značný vplyv na vymedzenie internetovej ekonomiky patrí:

- penetrácia internetu,

- aktivity používatel'ov v prostredí internetu,

- on-line nakupovanie a

- samotný vplyv internetu na produktivitu ekonomických subjektov. 
Penetrácia internetu v rámci Slovenskej republiky bola k 31.6.2011 74,2 \% (Zdroj: internetworldstats.com), čo je na rovnakej úrovni ako štáty Estónsko, Rakúsko či Belgicko. Penetrácia v Českej republike je približne 64 \%. Severské štáty majú 80 \% penetráciu. [3]

V roku 2011 bolo k pevnej širokopásmovej sieti 991403 pripojení, z toho bytových účastníkov bolo 804827 . V percentuálnom vyjadrení predstavuje penetrácia pevnej širokopásmovej siete na Slovensku len 18,37 \%. Najčastejšie využívanými technológiami sú xDSL, pripojenie cez rozvody káblovej televízie, FTTx (FTTH/FTTB), pripojenie cez rádiový prístup či družicové pripojenie. Na druhú stranu celkový počet pripojení cez mobilné siete predstavoval 2603983 populácie (3G/FDD, 2G (GPRS/EGDE), 3G/HSxPA, FlashOFDM).[4]

Európska únia si v rámci zabezpečenia a skvalitnenia širokopásmového pripojenia určila niekol'ko strategických ciel'ov. Na Obrázku 1 môžeme vidiet' plnenie ciel'ov Digitálnej agendy EÚ, pričom oranžová farba predstavuje splnenie ciel'ov za rok 2010 a modrá farba dosiahnutie ciel'ov za rok 2011. Práve biele miesta predstavujú značné slabiny. Najbližším ciel’om je sprístupnenie širokopásmového pripojenia všetkým obyvatel'om Európy do roku 2013. Do roku 2020 mieni Európska únia zabezpečit' rýchlost' pripojenia s viac ako $30 \mathrm{Mbit} / \mathrm{s}$ a zároveň polovica obyvatel'ov by malo mat' prístup na internet s prenosovou rýchlost'ou 100 Mbit/s. [3]

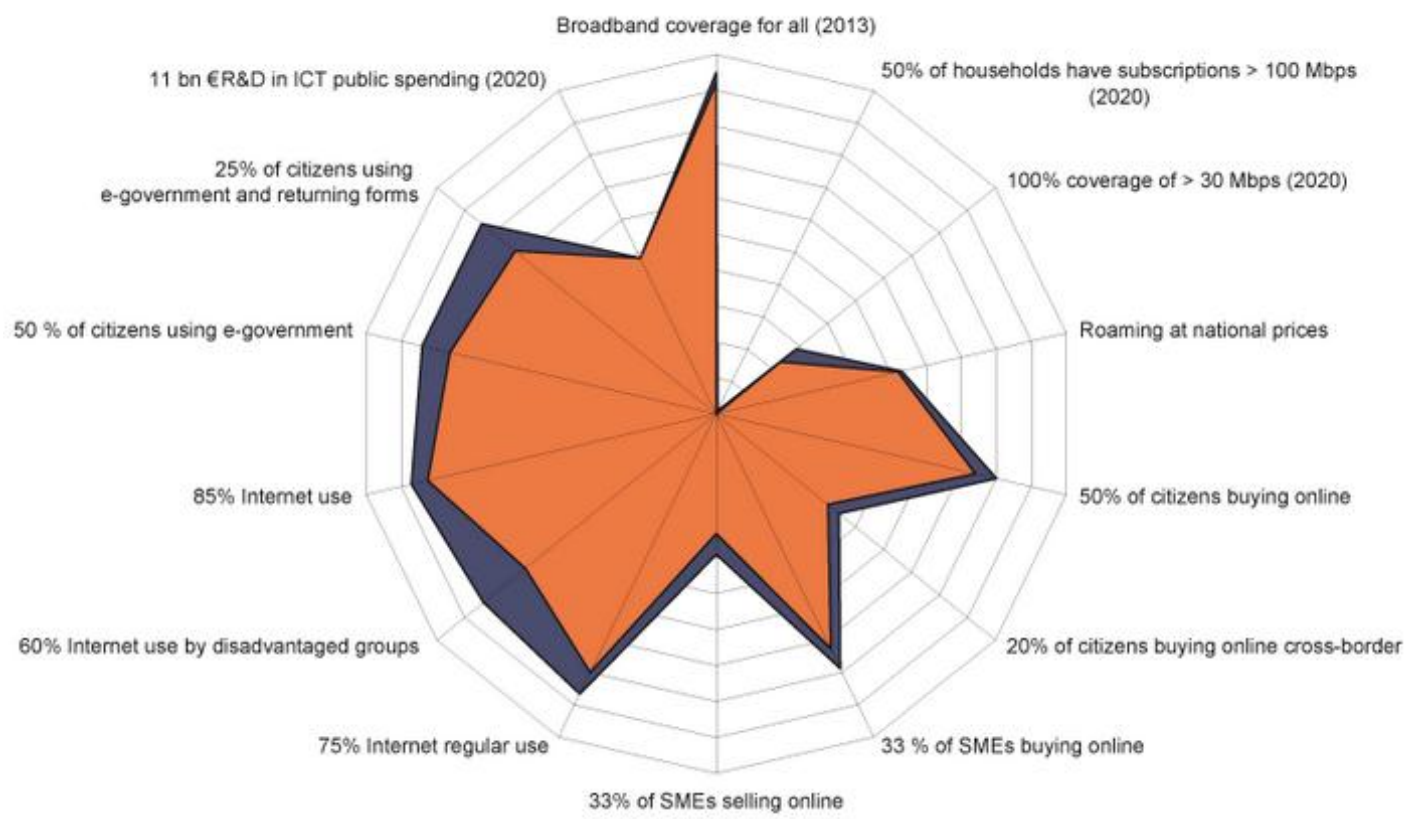

Orange $=2010$, dark blue $=2011$. Labels refer to targets; outerline is $100 \%$ achievement; targets refer to 2015 unless otherwise stated. $20 \%$ reduction in energy use not included.

Obrázok 1. PInenie ciel'ov Digitálnej agendy EU [Zdroj: dostupné on-line http://ec.europa.eu/information_society/digital-agenda/scoreboard/index_en.htm]

Návrh zabezpečenia širokopásmového pripojenia pre obyvatel'ov Slovenskej republiky do roku 2013 je zapracovaný do ciel'ov vlády SR. Na Slovensku bolo k minulému roku 780 obcí $(27,48 \%)$ mimo pevného širokopásmového pripojenia. Ide celkovo o 7,06 \% obyvatel'ov. Do budúcna sa kladie vel'ký dôraz na využívanie mobilných sietí k pripojeniu na internet, k čomu dopomáha aj narastajúca popularita smartphonov na trhu.[4]

Aktivity používatel'ov v prostredí internetu. Využívanie internetu na dennodennej báze má za posledné roky stúpajúcu tendenciu. Na území Slovenskej republiky zaznamenalo pripojenie na internet oproti roku 2010 nárast o $3 \%$ (2010 - 67,7 \% a v roku 2011 malo 75,4 $\%$ domácností prístup na internet). Naopak $29 \%$ opýtaných respondentov v roku 2011 
uviedlo, že doma nemá prístup na internet, pričom najčastejším dôvodom bola absencia skúseností, prípadne pokladajú internet za nepotrebný. To môžeme pripisovat' starnutiu obyvatel'stva, či stále nedostatočnej internetovej infraštruktúre. Ako už bolo spomenuté, internet sa stal každodennou súčast'ou súkromného a pracovného života. Nad’alej však v rámci EÚ štvrtina populácie vo veku od $16-74$ rokov nikdy internet nepoužívala. V porovnaní s Európskou úniou sa denne pripája k internetu $56 \%$ používatel'ov. V rámci členov EÚ sa až 80 \% obyvatel'ov denne pripája na internet v nasledujúcich štátoch: Dánsko, Holandsko, Fínsko, Švédsko a VB. Denne využíva internet okolo $60 \%$ obyvatel'ov štátov Bulharsko, Grécko, Taliansko, Cyprus, Pol'sko, Portugalsko a Rumunsko. Najčastejšími aktivitami európskych používatel'ov je vyhl'adávanie informácií o produktoch a službách (80 $\%$ ), viac ako polovica číta dennú tlač (56\%), rezervujú si letenky a ubytovanie alebo sledujú a hl'adajú informácie ohl'adom zdravia (54\%). Denne $40 \%$ opýtaných využíva internet na hl'adanie informácií ohl'adom vzdelávacích inštitúcií, on-line kurzov a podobne. [2][3]

V rámci Slovenskej republiky využívalo denne, alebo skoro každý deň 75,7 \% obyvatel'ov, čo predstavuje pokles oproti roku 2010 o 0,4 \%. Väčšina obyvatel'ov využíva internet denne na prijímanie a odosielanie e-mailov. Trend v rokoch $2010-2011$ bol poznamenaný narastajúcou popularitou sociálnych sietí. Na Slovensku realizovalo za rok 2010 aktivity v tomto prostredí viac ako polovica opýtaných obyvatel'ov (51,3 \%), pričom v roku 2011 sa tento podiel zvýšil o 12,9 \% (64,2 \% v roku 2011). V nasledujúcom obrázku môžeme vidiet' najčastejšie aktivity realizované slovenskými používatel'mi v rokoch 2010 a 2011v percentuálnom vyjadrení.[2]

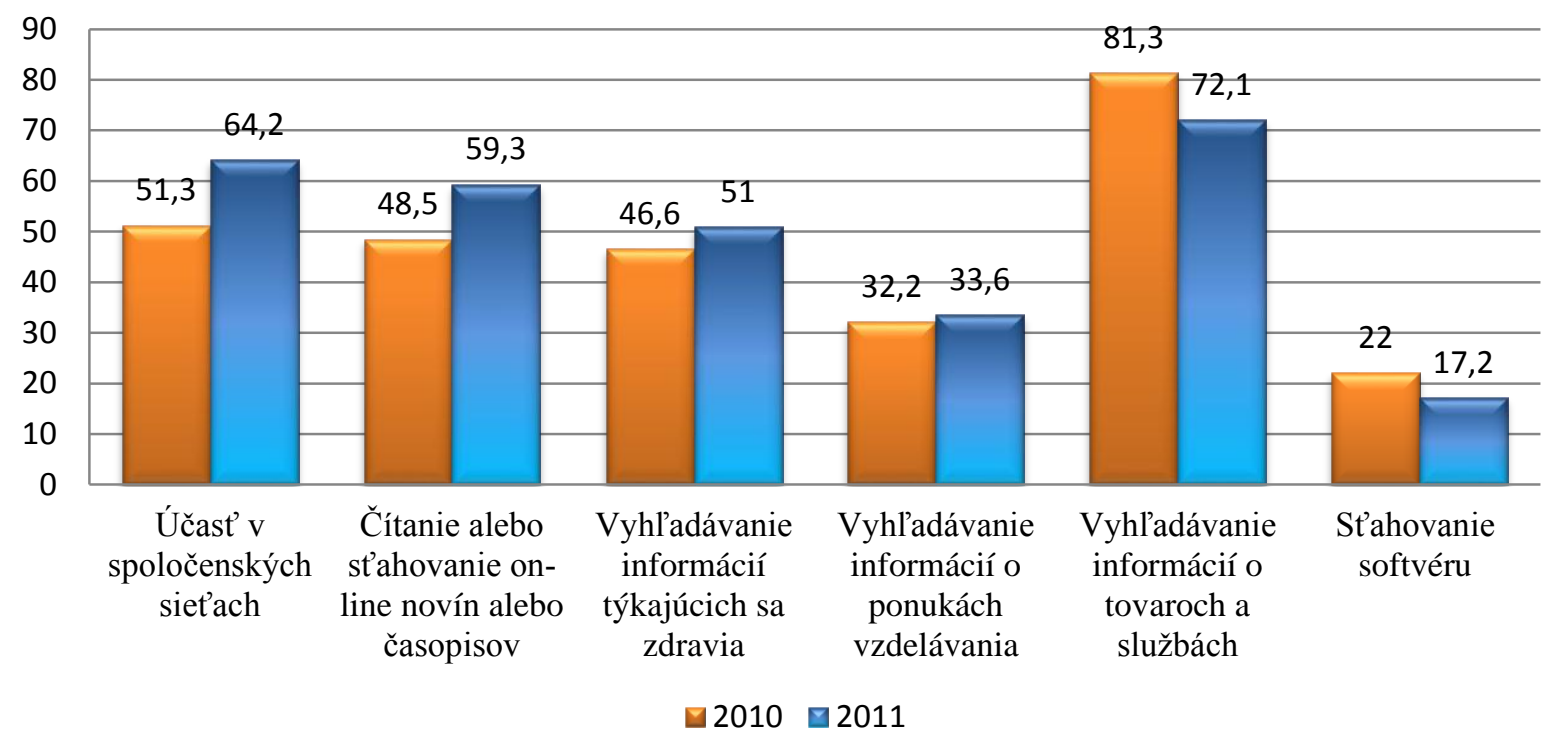

Obrázok 2. Najčastejšie realizované činnosti na internete (\%) [Zdroj: vlastné spracovanie, www.statistics.sk]

Nakupovanie na internete. Internetové nakupovanie je čoraz oblúbenejším fenoménom aj v rámci Slovenska. Prístup 24 hodín denne, 7 dní v týždni, nakupovanie z pohodlia domova a prístup $\mathrm{k}$ širokému sortimentu produktov, oslovilo takmer každú vekovú kategóriu. V roku 2011 takmer 28,3 \% l’udí nakúpilo na internete v priebehu troch mesiacov, sporadicky nakupuje 17,6 \%, iba raz za rok 13,9 \% a vôbec nenakupovalo 39,9\%. Najpopulárnejšou komoditou bol odev a športový tovar, tovar pre domácnost' alebo knihy a časopisy. Najmenší záujem bol o nákup podkladov pre elektronické štúdium, liekov a jedla. Internet je významným a primárnym prostredníkom pri rezervácií ubytovania, leteniek alebo lístkov na rôzne podujatia, čo v konečnom dôsledku z ekonomického hl'adiska môže a má vel'ký prínos. [2] 
Situácia v rámci Európskej únie za rok 2011 v oblasti elektronického obchodu mala podobný charakter. Traja z piatich internetových použivatel'ov nakúpilo na internete za posledných dvanást' mesiacov. Čoraz častejšie sa stretávame s javom, že väčšina používatel'ov berie internet len ako nástroj na zistenie informácií o tovaroch, službách, cenách, ale konečný nákup zrealizujú v kamennom obchode. Dôvodom môže byt' absencia možnosti tovar vyskúšat', zlé referencie internetového obchodu, obavy zo zneužitia osobných údajov alebo nedôvera prenosu finančných prostriedkov pomocou elektronických platobných systémov. Samozrejme internet so sebou priniesol d’alšiu významnú zmenu tým, že umožňuje prekonávat' vel'ké geografické vzdialenosti, čo z podnikatel'ského hl'adiska môže mat' vplyv na export a import.[3]

Zvyšovanie produktivity. Zavedenie a adaptácia nástrojov a procesov elektronického obchodovania, elektronického podpisu alebo elektronickej fakturácie má podl'a štúdie Európskej komisie pozitívny dopad na produktivitu práce. Štúdia Svetovej banky toto tvrdenie podporuje, s doplnením, že rozvoj a zabezpečenie širokopásmového pripojenia má pozitívny dopad ako na jednotlivca, tak aj na firmy, a tým prispieva ku globálnemu ekonomickému rastu.[6]

\section{Zmeny v podnikatel'skej sfére s nástupom internetu}

Ako už bolo v článku spomenuté, internet plne zasiahol takmer každého jednotlivca a firmy. Ovplyvnil procesy vo viacerých odvetviach a firmám poskytol nasledovné pozitívne zmeny, ako napr.:

- Zníženie počtu sprostredkovatel'ov, partnerov, čím zabezpečil transparentnost'.

- Zlepšil vzájomné vzt’ahy medzi zákazníkmi, dodávatel'mi a partnermi.

- Automatizovaná a efektívnejšia výmena informácií v rámci SCM (riadenie vzt'ahov z dodávatel'mi) systémov.

- Efektívnejšie cielenie reklamných a predajných aktivít, pomocou „Long tail““, t. j. predaj produktov malým skupinám spotrebitel'ov.

- Geografické pokrytie bez nutnosti budovania kamenného obchodu alebo siete kamenných obchodov na nových trhoch.[6]

Internet zasiahol a ovplyvnil inováciu nákupného procesu. Začali vznikat' čisto internetové obchody, prípadne pôvodné podnikatel'ské riešenia sa rozšírili o internetový predaj. Tento efekt ovplyvnil celý podnikatel'ský či dodávatel'ský ret’azec. Vplyv internetu mal výrazný efekt aj v oblasti bankovníctva, poštových služieb alebo cestovného ruchu.

Od nepamäti je primárne chápaný ako komunikačný kanál. V súčasnej dobe je čoraz viac a viac využívaný ako informačný prostriedok, resp. priestor pre získavanie informácií ohl'adom tovarov, služieb, získavanie referencií a podobne. Tým, že internet predstavuje informačný nástroj, museli sa aj klasické oznamovacie prostriedky prispôsobit' novým trendom. Oznamovacími prostriedkami v tomto zmysle chápeme dennú tlač. Takmer všetky denníky na Slovensku sú prístupné aj v elektronickej podobe. Spravodajský portál webnoviny.sk mal za posledné tri mesiace tohto roku najvyšší počet návštev a zobrazených stránok. V marci 2011 zaznamenal takmer 430 tisích unikátnych návštevníkov (Zdroj: SITA). Potenciál sociálnych sieti našiel svoje uplatnenie aj vo sfére spravodajských portálov. Jednou z najvýraznejších benefitov sociálnych sietí je zdielanie informácií. Najpopulárnejšia siet' Facebook začiatkom apríla tohto roku spustila stránku mediálnych zdrojov zameranú na vysvetlenie a pomoc pri využívaní nového spravodajského nástroja, ktorý umožňuje efektívnejšie nadviazat' spojenie s čitatel'om. V USA sú sociálne siete prevažne využívané na dve hlavné činnosti, a to na komunikáciu s priatel'mi a získavanie každodenného spravodajstva. Využitel'nost' tohto nástroja sa začína čoraz viac uplatňovat' aj v podmienkach Slovenskej republiky. Potenciál na to má, ked’že viac ako polovica slovenskej populácie sa pripája denne na sociálne siete. [5] 
Bankovníctvo predstavuje d'alšie odvetvie, ktorému internet výrazne dopomohol $\mathrm{v}$ procese inovácie a technologického pokroku. S nástupom internetu sa postupne čoraz viac začína využívat' internetové bankovníctvo. Najvýraznejší efekt priniesol v zmene interakcie banky so svojimi klientmi. V rámci Slovenskej republiky, za min. rok, využívalo internet banking 45,5\% respondentov, čo predstavuje nepatrný dvojpercentný nárast oproti predchádzajúcemu roku. Zavedenie malo pozitívny efekt v znížení nákladov pri poskytovaní služieb zákazníkom, zníženie časovej náročnosti na spracovanie agendy a efektívnejšie cielenie zákazníckych ponúk. Predstavuje tiež vyššiu transparentnost' cien, ked’že internet umožňuje na jednom mieste porovnat' ponuky od viacerých bánk. [2]

Poštové služby tiež internet priaznivo ovplyvnil. Podpísalo sa pod to predovšetkým vznik elektronických obchodov, ktoré najčastejšie využívajú ako distribučný kanál služby pošty pre doručovanie balíkových zásielok zákazníkom. Pol'ská pošta zaviedla novú on-line platformu, zameranú výhradne na balíkové zásielky. Zákazníci tu nájdu aktuálne nové služby, ako obchodné a zasielacie podmienky alebo aktuálnu ponuku balíkových služieb. Stránka je viac transparentná. Ul'ahčuje prístup ku informáciám o cene a príprave zásielok (elektronické formuláre, žiadosti, vzory adries). Inováciou je zavedenie balíkového asistenta, ktorý na základe zadaných údajov o hmotnosti zásielky, dodacej lehote vyfiltruje najvýhodnejšiu balíkovú službu z hl'adiska ceny a logistiky.

Cestovný ruch využíva internet ako informačný kanál na propagovanie služieb, destinácií a miest na internetových stránkach cestovných agentúr, čo výrazne prispieva $\mathrm{k}$ nárastu návštevnosti jednotlivých destinácií. Internet umožňuje rýchlu a efektívnu on-line rezerváciu, čo predstavuje výhodu v transparentnosti tým, že používatel' má na jednom mieste dostatočné množstvo informácií ohl'adom ubytovania, cestovných lístkov a pod. Výhodou je prístupnost' referencií, čo do vel'kej miery ovplyvňuje nákupné rozhodovanie. Celosvetovo môžeme hovorit' o troch najrozšírenejších spôsoboch on-line rezervácie:

a) Rezervácia priamo na webovej stránke cielovej destinácie (konkrétny hotel, destinácia).

b) Návšteva špecializovaných webových stránok cestovných agentúr, sústred’ujúcich viaceré ponuky.

c) Návšteva webových stránok konkrétnych cestovných agentúr pôsobiacich v off-line prostredí.

Pri rezervácií leteniek je rýchlym a efektívnym nástrojom, ked’že si internetový používatel' môže porovnat' cenu, dobu letu, leteckú spoločnost', možnost' prestojov prípadne využit' last minute ponuku, ktorá býva niekedy aj s 50 - 70 \% zl'avou z pôvodnej ceny letenky.[3]

\section{Záver}

Výhody a zmeny, ktoré so sebou priniesol internet sú nepopieratel'né. Vo väčšine odvetví a činnostiach má niekol'ko spoločných atribútov, a to: vyššia transparentnost', pohodlnost', časová a nákladová efektívnost'. Pre podniky a jednotlivé odvetvia sa viaceré činnosti automatizovali, čo sa prejavilo v znížení administratívneho a finančného zat'aženia. Mohlo by sa zdat', že internetový potenciál bol už maximálne využitý, ale neustále sa objavujú nové priestory na inovatívne myšlienky a projekty.

\section{Literatúra}

[1] MADLEŇÁK, R., VACULÍK, J.: Elektronické podnikanie, EDIS, Žilina, 2009, 232 str., ISBN 978-80-8070-952-5

[2] Štatistický úrad SR, 2012 [online], [cit.18-04-2012], Dostupné na internete:

< http://portal.statistics.sk/showdoc.do?docid=41771> 
[3] Eurostat.eu. European Commicion. Digital agenda 2020, 2012 [online], [cit.18-04-2012], Dostupné na internete: <http://ec.europa.eu/information_society/digital-agenda/scoreboard/index_en.htm>

[4] Telekomunikačný úrad SR online], [cit.18-04-2012], Dostupné na internete: <http://www.telecom.gov.sk/files/statistika_vus/telekom/index.htm>

[5] SITA - Facebook zvyšuje návštevnost' spravodajských portálov, 2012 [online], [cit.1804-2012], Dostupné na internete: 〈http://www.itnews.sk/spravy/internet/2011-0411/c139414-facebook-zvysuje-navstevnost-spravodajskych-portalov>

[6] Prípadová studie, Zemně internetova 2012. [online], [cit.18-04-2011], Dostupné na internete: 〈http://www.zemeinternetova.cz/case-studies.php>

\section{Grantová podpora}

Článok bol spracovaný v rámci riešenia projektu VEGA č. 1/0687/11 Hodnotenie stavu Business Excellence 